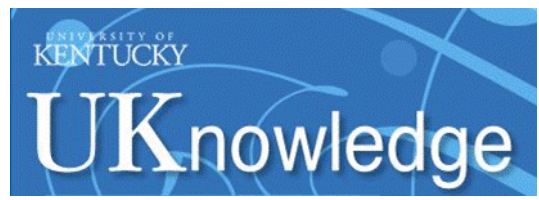

Journal of Natural Resources \&

Environmental Law

Volume 15

Issue 1 Journal of Natural Resources \&

Environmental Law, Volume 15, Issue 1

Article 4

January 1999

\title{
The Economics and Ethics of Land Reform: A Critique of the Pontifical Council for Justice and Peace's "Toward a Better Distribution of Land: The Challenge of Agrarian Reform"
}

Walter Block

University of Central Arkansas

Guillermo Yeatts

Phoebus Energy, Ltd.

Follow this and additional works at: https://uknowledge.uky.edu/jnrel

Part of the Land Use Law Commons

Right click to open a feedback form in a new tab to let us know how this document benefits you.

\section{Recommended Citation}

Block, Walter and Yeatts, Guillermo (1999) "The Economics and Ethics of Land Reform: A Critique of the Pontifical Council for Justice and Peace's "Toward a Better Distribution of Land: The Challenge of Agrarian Reform"," Journal of Natural Resources \& Environmental Law: Vol. 15: Iss. 1, Article 4. Available at: https://uknowledge.uky.edu/jnrel/vol15/iss1/4

This Article is brought to you for free and open access by the Law Journals at UKnowledge. It has been accepted for inclusion in Journal of Natural Resources \& Environmental Law by an authorized editor of UKnowledge. For more information, please contact UKnowledge@lsv.uky.edu. 


\title{
THE ECONOMICS AND ETHICS OF LAND REFORM: A CRITIQUE OF THE PONTIFICAL COUNCIL FOR JUSTICE AND PEACE'S "TOWARD A BETTER DISTRIBUTION OF LAND: THE CHALLENGE OF AGRARIAN REFORM"
}

\author{
WALTER BLOCK* AND GUILLERMO YEATTS**
}

\section{INTRODUCTION}

Land reform can be defined as the forced transfer of the ownership of land from one person to another. This must be distinguished from the voluntary transfer of land from one person to another, such as ordinary buying and selling. In the latter case, there can be no true third party. All those involved in land purchases -agents, insurers, lawyers -- are mere agents of one party or the other to the agreement. But in the former there must be a third actor, the one who forces one party to give up his land to a second party. This third party is typically the government. Were this third party not involved in the process, there could be no land reform.

In most land reform debates only two sides are represented. These two, together, dominate all such discussions. On the one hand there are those, usually called conservatives or right wing activists, who oppose land reform per se. ${ }^{1}$ They maintain that such forced transfers are in total opposition to private property rights. From this perspective land reform must be stopped, as private property rights are the very bedrock of civilization. Once these rights are breached all law, to say nothing of the economic well being of the populace, is in grave danger.

On the other hand there are those, usually called socialists or left wing activists, who maintain that land reform is justified if and only if the donors of the land are rich or powerful and the recipients are poor

\footnotetext{
*Chairman, Department of Economics and Finance, University of Central Arkansas.

${ }^{* *}$ Chairman, Phoebus Energy, Ltd. B.S., M.A. New York University, OPM Harvard University Graduate School of Business Administration.

'See LUDWIG Von MISES, SOCIALISM 45 (J. Kahane trans., Yale University Press 1951); see also DAVID FRIEDMAN, THE FraSER INSTITUTE, MORALITY OF THE MARKET: RELIGIOUS AND ECONOMIC PERSPECTIVES 497-98, 506-07 (1985).
} 
or powerless. Their argument is one of equity. Socialists maintain that the privileged of the world are few; they own vast tracts of land which are often not cultivated. In contrast, many people are poor and on the verge of starvation. They have the labor power necessary to feed themselves, but not the land upon which to do this.

One of the purposes of this paper is to explore a third alternative in this debate, the libertarian or classical liberal position. This analysis is important for three reasons. First, the other two perspectives are at loggerheads. There is, seemingly, no possible reconciliation between them. It is possible that the introduction of a third philosophy of property rights and land reform may serve as an ameliorating device, allowing each of the other two parties to compromise with one another. Here, we speak not of compromise in the sense of adding up the differences and dividing by two, but rather of a principled compromise where each is able to retain the best part of its vision. Second, we shall maintain that while both the socialist and conservative view have aspects of justice on their side, neither has a monopoly in this regard. As presently constituted, both appear fatally flawed. Each philosophy, however, shares certain libertarian elements. If these can be brought out into the clear light of day, we can more closely approximate the truth of the matter. In this essay, we shall attempt to c.fer the view that only the classical liberal vision is in accord with justice.

Finally, even if we cannot fully succeed in defending this rather ambitious claim, this exercise will still prove beneficial by providing a third alternative for society to consider. It may well be that this dialogue, now intellectually dead in its tracks, may take on some new light with the advent of a third viewpoint.

\section{LIBERTARIAN LAND REFORM}

\section{A. The Libertarian Philosophy of Land Reform}

What, then, is the libertarian philosophy of land reform? Such a theory maintains both that forced transfers of land from one person to another are justified, and that far from being incompatible with a strict 
regime of private property rights, land transfers are sometimes required by this doctrine. While these transfers are often from rich to poor, this is not required. It is even possible that justified land reform may enrich the wealthy and impoverish the poor. Conservatives may therefore find comfort in the fact that the libertarian position strongly upholds private property rights, while socialists may exult in the fact that land reform is not prohibited by the libertarian doctrine.

How can we reconcile these seemingly irreconcilable claims? It is simple. Valuable items are sometimes stolen. When these items are forcibly returned to their rightful owners, private property rights are protected. The following example supports this position:

Suppose we are walking down the street and we see a man, A, seizing B by the wrist and grabbing $B$ 's wristwatch. There is no question that $A$ is here violating both the person and property of $B$. Can we then simply infer from this scene that $A$ is a criminal aggressor, and $\mathrm{B}$ his innocent victim?

Certainly not -- for we don't know simply from our observation whether $A$ is indeed a thief, or whether $A$ is merely repossessing his own watch from $B$ who had previously stolen it from him. In short, while the watch had undoubtedly been B's property until the moment of A's attack, we don't know whether or not A had been the legitimate owner at some earlier time, and had been robbed by $B$. Therefore, we do not yet know which one of the two men is the legitimate or just property owner. We can only find the answer through investigating the concrete data of the particular case, i.e., through 'historical' inquiry.

Thus, we cannot simply say that the great axiomatic moral rule of the libertarian society is the protection of property rights, period. For the criminal has no natural right whatever to the retention of property that he has stolen; the aggressor has no right to claim any property that he has acquired by 
aggression. Therefore, we must modify or rather clarify the basic rule of libertarian society to say that no one has the right to aggress against the legitimate or just property of another.

In short, we cannot simply talk of defense of 'property rights' or of 'private property' per se. For if we do so, we are in grave danger of defending the 'property right' of a criminal aggressor -- in fact, we logically must do so. ${ }^{2}$

The libertarian, then, must favor this "wristwatch" reform, as A is the proper owner of the stolen property, while B is merely its criminal possessor. Consider, however, the following situation: $B$, the thief, passed the watch down to $\mathrm{B}^{\prime}$, his son, whereupon $\mathrm{B}^{\prime \prime}$, the grandson, inherited the watch and currently has possession. Presume also that had A not had the time piece stolen from him, it would have ended up the property of $\mathrm{A}^{\prime \prime}$, through a similar inheritance process. At this point $\mathrm{A}^{\prime \prime}$ goes to the police and demands the return of the watch from B". The latter objects that it is his private property, and to engage in the "wristwatch reform" described above constitutes socialism or communism. With our libertarian insights, however, it is easy to see the error of this response. Protecting B" under these conditions would not uphold private property rights, but rather would denigrate them. B" simply has no leg to stand upon. While he is not a thief, he is the possessor of what must be considered stolen property. To allow him to continue holding the watch would be to keep it from its rightful owner, A".

Of course, in this scenario the burden of proof rests squarely with $\mathrm{A}^{\prime \prime}$, the person attempting to alter and abolish present property titles. As the old legal adage goes, "Possession is nine tenths of the law," as it is the best evidence, in our uncertain world, of legitimate title. But this is only a presumption. With appropriate evidence, it can be defeated. If $\mathrm{A}^{\prime}$ can prove he is the just owner, then the watch should be returned to him. If somehow the forces of law and order could travel

${ }^{2}$ Murray Rothbard, The Ethics OF Liberty 51-52 (1982). 
back in time to capture B, the robber, they would be entitled to do more than merely relieve him of his ill gotten gains. ${ }^{3}$ While $\mathrm{B}^{\prime \prime}$ is entirely innocent of the original crime, it would be a denial of private property rights to allow him to keep this stolen watch.

The problem with the conservative position is that it sometimes amounts to a defense of thieves. Since the conservative philosophy is linked with capitalism in the public mind, the free enterprise system is widely dismissed as merely upholding the "survival of the fittest," or of the claims of the rich against the poor. But nothing could be further from the truth. Free enterprise does not at all condone land,or any other kind, of theft; rather, this doctrine advocates the return of stolen property.

If the libertarian position deviates from the conservative philosophy, it also differs with the socialist view of redistribution from rich to poor. To put this another way, libertarians agree with the conservative advocacy of private property rights, but not with the claim that it constitutes a legitimate defense of all extant property titles. Rather, the libertarians agree with the socialists that forced transfer of property titles are sometimes justified when it is necessary to effectuate justice.

\section{B. Property Redistribution}

What is morally wrong with the socialist vision of coercively taking possessions from rich people and giving them to the poor? First, it is theft, and civilized societies have always looked askance upon such actions. To the extent that massive stealing becomes the order of

\footnotetext{
${ }^{3}$ See generally RANDY BARNETT \& JOHN HAGEL, ASSESSING THE CRIMINAL 309-21 (1977); Charles J. King, A Rationale for Punishment, 4 J. LIBERTARIAN STUDIES 151, 154 (1980); Stephan N. Kinsella, A Libertarian Theory of Punishment and Rights, 30 LOYOLA L. REv. 607 , 613 (1997); Stephan N. Kinsella, New Rationalist Directions in Libertarian Rights Theory, 12 J. LiBertaRIAN StUdies 313, 321 (1996); Stephan N. Kinsella, Punishment and Proportionality: The Estoppel Approach, 12 J. LIBERTARIAN STUDIES 51, 57 (1996); Stephan N. Kinsella, Estoppel: A New Justification for Individual Rights, Reason Papers No. 17 (Fall 1992); Stephan N. Kinsella, Inalienability and Punishment: $A$ Reply to George Smith, 14 J. LIBERTARIAN STUDIES 79-93 (1998); MURRAY ROTHBARD, THE ETHICS OF LIBERTY 51-55 (1982).
} 
the day, a social breakdown is the inevitable result. The Ten Commandments prohibit not only robbery, but even coveting the property of others. ${ }^{4}$

Additionally, egalitarians are unable to follow the Kantian imperative to make their principles the basis upon which all men act; ${ }^{5}$ if we may redistribute land and presumably money from rich to poor, then why may we not steal from the rich and give to the poor those characteristics which have allowed them to become wealthy in the first place? That is, assuming we had the ability to do so, we could take away the musical ability of Mozart, the athletic accomplishments of Michael Jordan, the entrepreneurial and innovational attainments of Bill Gates, the intelligence of Steven Hawking and the sense of humor of Jay Leno. Were we to engage in such egalitarian redistribution, and continue the process until there were no difference between those rich and poor in talent and characteristics, we would have truly reduced the human race to the undifferentiated blob of a Brave New World ${ }^{6}$

Third, there is simply no practical reason to engage in land reform from rich to poor if the goal is to help the poor attain a better standard of living. If there is one thing that most people have learned in the last few decades (or, in any case, should have learned) it is that the last best chance for lifting the poor out of poverty is not to give them the property of others, but rather grant them economic freedom. ${ }^{7}$ In comparison to other factors, the redistribution of land does little to increase overall wealth.

Support for this position can be found in economist David Friedman's critique on the redistribution of Native American land in the United States, wherein he wrote,

${ }^{4}$ See Exodus 20:1-17.

${ }^{5}$ See Immanuel Kant, Theory and Practice II; Introduction to the Theory of Right, in KANT's POLITICAL WRITINGS (Hans Reiss ed. \& H.B. Nisbet trans., Cambridge Univ. Press 1970).

${ }^{6}$ Aldous HuXley, BRAVE NEW WORLd (1946).

${ }^{7}$ See JAMES GWARTNEY ET AL., ECONOMIC FREEDOM OF THE WORLD 1975-1995 151 -70 (1996); see also HERNANDO DE SOTO, THE OTHER PATH: THE INVISIBLE REVOLUTION IN THE THIRD WORLD 214-29 (1989); ANTHONY DE JASAY, THE STATE 208-32 (1985); HANSHeRMANN HOPPE, A THEORY OF SOCIALISM AND CAPITALISM: ECONOMICS, POLITICS AND ETHICS 56 (1989). 
In the U.S. at the moment, if you gave the country back to the Indians, in some fair way where you didn't give them the buildings that are built on it, but just the land; and divided it fairly evenly among the Indians, it would not noticeably affect the distribution of income in the U.S. It wouldn't much affect how well off $\mathrm{I} \mathrm{am}^{8}$

\section{HOMESTEADING}

How, in the libertarian view, is an original claim to land justified? We begin our analysis with an excerpt of John Locke's homesteading theory, wherein he states:

[E]very man has a property in his own person. Thus nobody has any right to but himself. The labour of his body and the work of his hands, we may say, are properly his. Whatsoever, then, he removes out of the state that nature hath provided and left it in, he hath mixed his labour with it, and joined it to something that is his own, and thereby makes it his property. It being by him removed from the common state nature placed it in, it hath by this labour something annexed to it that excludes the common right of other men. For this labour being the unquestionable property of the labourer, no man but he can have a right to what that is once joined. ${ }^{9}$ [Emphasis added]

The above serves only as a starting point. Locke applies his theory only in cases where there is a superfluity of land. In other

\footnotetext{
${ }^{8}$ David Friedman, Discussion, in MORALITY OF THE MARKET: RELIGIOUS AND ECONOMIC PERSPECTIVES 505 (Walter Block et al. eds., 1985)

${ }^{9} \mathrm{JOHN}$ LOCKE, An Essay Concerning the True Original, Extant and End of Civil Government, in Two TREATISES OF GOVERNMENT (P. Laslett, ed. 1960).
} 
words, where there is enough virgin land so that no man can homestead it all, there is plenty left for the use of others. Libertarians, in contrast, believe the Lockean theory should be applied in all cases, whether or not there are sufficient land resources available for other people. ${ }^{10}$

What is the alternative to Locke in general or, more specifically, for the cases where excess land is not available? Several possibilities exist, the first of which is the claim theory. Under this approach, a man gets to own land or other natural resources merely by assertion. "I claim the sun, the moon, the stars, and the oceans," a man might say, and, if he is the first to do so, he thereby becomes the legitimate owner. The problems with this are legion. Who will know who has claimed what? There could be numerous people claiming the same thing at the same time; this theory offers no way to choose between them. According to folk wisdom, "talk is cheap." Anyone can say anything he wants, and as such, mere speech should not entitle anyone to own anything.

A second approach utilizes the apparatus of the state. With regard to unowned land, the government can give this property to its favorites, sell it to the highest bidder in an auction, or parcel it out on a first-come-first-serve basis." bureaucrats own unused land? What did they do to deserve proprietary status? Even if the government sells the land instead of giving it away, the government already has far too many resources; why should they possess any more?

Third, there is the doctrine of equal shares for all individuals. To illustrate, if there are six billion of us, then we all own one six billionth of all virgin land. This is rather arbitrary, as we do not all own equal shares of anything else, up to and including human capital. The following example by Professor Rothbard illustrates the problem inherent in this theory: "It is difficult to see why a newborn Pakistani baby should have a moral claim to a quotal share of ownership of a

\footnotetext{
${ }^{10}$ See RothBARD, supra note 3 , at 53.

${ }^{11}$ See, e.g, U.S. Homesteading Act, 12 U.S. Statutes at Large, $\$ 75$ et seq. (1862).
} 
piece of Iowa land that someone has just transformed into a wheatfield -- and vice versa of course for an Iowan baby and a Pakistani farm."12

A fourth possibility is the theory of communal ownership with proportionate distribution of shares. In this view, we do not each own one six-billionth of all virgin land on an individual basis; rather, we own it all, communally. In other words, before anything can be done with specific pieces of land, all of us, or at least a majority, must agree. This sounds like either a recipe for interminable committee meetings or, more likely, the concentration of power in a small set of the population.

A fatal flaw in all of these theories can be illustrated not with the ownership of land, but of something even more important, the human person. Civilized people agree to individual ownership of ourselves. This is consistent with homesteading. Initially, when we are born, we are unable to "homestead ourselves," or rather, mix our labor with our own persons. Our parents perform tasks for us and thus, in a sense, "own" us throughout infancy. ${ }^{13}$ Then, as we reach adulthood, we gradually take control over our bodies, or "homestead" them in effect, and thus come to own them fully. Perhaps an application of the above mentioned theories of property ownership to the ownership of people will prove insightful.

Under the claim theory, anyone could claim control over anyone else, provided only that he was the first to do so. This is a recipe for slavery on a grand scale, and must be rejected on that basis alone. Government ownership of people is similarly unacceptable. This merely shifts the slave master from the first claimant to the state. Or, to put this in another manner, it would hearken back to medieval days in Europe, or to Oriental despotism, where the king was considered the literal owner, to do with as he wished, with all his subjects. Likewise, the theory of equal shares for all individuals is also unsatisfactory. Obviously, if we were to do things in this way, Michael Jordan and Bill Gates would have been given far more than an equal share. They would, at least partially, have to do the bidding of the rest

\footnotetext{
12 Murray N. Rothbard, FOR A New LiberTy 35 (1973).

${ }^{13}$ More exactly, own the right to keep raising, or homesteading us. For the libertarian perspective on children, property and ownership. See id. at 97-112.
} 
of us. Who could argue in favor of ordering around some people merely because they were born with or developed extra talents and abilities? Finally, communal ownership also fails when it comes to control over human beings. If interpreted literally, no individual could so much as scratch his nose without the permission of at least a majority of six billion people. Under such a system, the human race would surely perish.

\section{THE PONTIFICAL COUNCIL'S DOCUMENT ${ }^{14}$}

\section{A. Concentration and Misappropriation of Land}

The Pontifical Council ("hereinafter Council") often refers to the phrase, "concentration and misappropriation of land" in a negative manner. ${ }^{15}$ But why must high concentration necessarily be equated with misappropriation? In the United States, there is high concentration in the computer, automobile and movie industries, which are dominated by a handful of very large and prosperous entities. The same phenomenon occurs with regard to the ownership of agricultural land in the United States, where the farming sector is a significant contributor to overall economic wealth. There are sizable farms and ranches, such as in Texas and Montana, which are measured not so much in acres, nor even in hectacres, but rather in square miles. Even so, apart from some Nader-ite attacks on "agribusiness," the large size of these farms has not led to, nor does it constitute, "misappropriation."

\footnotetext{
${ }^{14}$ Roger Card et al., Toward a Better Distribution of Land: The Challenge of Agrarian Reform, NAT'L CATH. REP., Vol 34, No. 22 (April 3, 1998). [hereinafter Presentation]. Our commentary is based on the organization of the Presentation. We shall not discuss each and every section, as there is much repetition between them, and some are irrelevant to our concerns. Indeed, the organization of this document, or rather lack of it, makes a reply to it rather difficult. There are several recurrent themes of interest, and we will comment on all of them, but some are spread all throughout the document, stated in slightly different formats each time.

${ }^{15}$ See id. para. 1, 2, 4. Indeed, there are very few paragraphs in the entire document which do not criticize "land concentration."
} 


\section{B. Developing Economies}

The Council continually uses the term "developing economies" to refer to the poor nations of the third world. The use of this phrase is highly inaccurate. Characterizing an economically deteriorating nation as "developing" cannot possibly materially help any nation or its citizens. An acknowledgment of the truth is the first step in correcting the real problems these nations are facing. Denial is of little use in either economics or psychology. The point is that many of these countries are not developing at all; some are barely holding their own, while others are actually retrogressing from an economic development point of view. The Council's choice of words camouflages this reality.

\section{Factors of Production}

In the Council's economic analysis, "land ... given the predominantly agricultural nature of the economy ... constitutes the fundamental production factor, together with labor, and the chief source of national wealth." ${ }^{16}$ This is a curious conclusion. The document under consideration is concerned solely with land reform. This would imply, given the goal of economic development, that land is the key factor in production. Why, then, is the phrase "together with labor" added to the statement? Could it be that the writers of this document realize that land reform is not all that important, even to a predominantly agricultural nation? This realization comes from the fact that labor, on the margin, contributes far more to GDP than land. ${ }^{17}$ Even in the undeveloped countries people own their own labor. Hence, this admission by the Council seriously undercuts their thesis.

This, however, is only the beginning of the problem. There are other factors of production beyond land and labor, most notably capital. But capital, based on savings and engendered by security of property

${ }^{16}$ Id. para. 1 (emphasis added).

${ }^{17}$ In 1992, labor's distribution of the United States National Income was $74.1 \%$. In 1980 this figure was $75.9 \%$, indicating only a slight variation. See Morgan Reynolds, ECONOMICS OF LABOR 55. 
rights, tends to avoid nations which engage in the socialist, egalitarian "reform" of land holdings, thus further leading to impoverishment. While no one can move land from one place to another, this immobility certainly does not apply to capital. The point is that the Council's thrust is in the direction of killing the goose which will, at least potentially, create the golden eggs.

\section{Preferential Option for the Poor}

The clergymen begin this section on a sound footing, with their

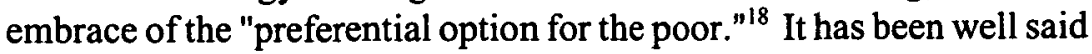
that a society may fairly be judged by how its poor are treated. If there is any obvious conclusion which must be drawn from an international economic comparison of countries, it is that the poor in rich nations are treated far more decently than those in the underdeveloped part of the world. If anything, the poor in places such as Switzerland, the United States and Canada boast of more material possessions than even the middle class in many parts of the globe. Were Roger Cardinal Etchegaray, the author of the Council's land reformation document, serious about improving the lot of the poor in the third world, he would advocate economic development of the sort enjoyed in Europe, North America, Japan and other such countries; that is, a great reliance on private property and free markets.

How did these wealthy nations achieve their present enviable economic status? Clearly, it was by embracing economic freedom, private property rights, and the rule of law. ${ }^{19}$ Therefore, anything the clergy advocate in this direction will be helpful to the poor. But

\footnotetext{
${ }^{18}$ Presentation, supra note 14 , para. 2.
}

${ }^{19}$ See generally PETER T. BAUER, REALITY AND RHETORIC: STUDIES IN THE ECONOMICS OF DEVELOPMENT 38-52 (1984); see also PETER T. BAUER, EQUALITY, THE THIRD WORLD, AND ECONOMIC DELUSION 86-102 (1981); HeRNANDO DE SOTO, THE OTHER PATH: THE INVISIBLE REVOLUTION IN THE THIRD WORLD 108-20 (1989); JAMES GWARTNEY ET AL., THE FRASER INSTITUTE, ECONOMIC FREEDOM OF THE WORLD, 1975-1995 36-42 (1996); F.A. HAYEK, LAW, LEGISLATION AND LIBERTY (1973); HANS-HERMANN HOPPE, A THEORY OF SOCIALISM AND CAPITALISM: ECONOMICS, POLITICS AND ETHICS 53-60 (1989); ADAM SMITH, AN INQUIRY INTO THE NATURE AND CAUSES OF THE WEALTH OF NATIONS 52-63 (Edwin Cannon, ed. 1965) (1776). 
anything in the opposite direction will be harmful, and thus contrary to the preferential option for the poor, the presumed motivating axiom of the entire document. How well then does the Cardinal's statement do when measured against these criteria? While there are some exceptions, the overall assessment, unfortunately, is negative. The analysis and evidence behind our assessment is explored below.

\section{Latifundia}

The Pontifical Council defines "latifundia" as "large land holdings, often belonging to absentee owners, where the land is worked on by hired labour, using out-dated farming techniques." ${ }^{20}$ This would be unexceptionable but for the fact that the Council sees the latifundia as a basic cause of the problems of the third world. ${ }^{21}$ What is the basis of this opinion? After all, as we have seen, "large land holdings" are characteristic of many countries with a vibrant agricultural sector, such as the United States and Canada.

Nor are "absentee owners" a barrier to economic development. Much real estate in advanced industrial nations is owned by people who do not live in their own high-rises. The corporation itself, emblem of economic success if ever there was one, is a paradigm case of "absentee ownership." Here, millions of people buy shares in companies which own land, mines, farms, resources all over a country, and, in the case of multinationals, all around the world. Surely stockholders are all "absentees." Are the clergy attacking the very idea of the corporation as economically unviable? One would have thought that with the toppling of the Soviet Union this sentiment would no longer be expressed quite so blatantly. It appears, however, that such thinking is wrong. Despite the Council's position, it is clear that an objective examination of economic reality shows that the criticism of the latifundia is misplaced.

\footnotetext{
${ }^{20}$ Presentation, supra note 14 , para. 2, n. 2 .

${ }^{21}$ See id.
} 


\section{Competence}

The Council states that its land reformation document "is not a document of political intent, for that lies outside the Church's field of competence." ${ }^{22}$ This issue would not have been brought up but for its entanglement with economics, since to do so would smack of argumentum ad hominem. It is not for us to state that only those with doctorates in economics are competent to analyze current economic issues, such as those involving the development of third world countries. However, since the Pontifical Council brought up this issue, perhaps it is appropriate to discuss it. In the Council's view, they are not competent to discuss political intent, but, presumably, they are competent to discuss economic development. But why the difference? Are they not theologians, therefore unqualified to also act as political scientists and economists? If so, what is the argument for competence in the latter but not the former?

\section{Mortgage of the Past}

The Council states that "[p]rivate appropriation of the land ... introduced serious distortions into the land market."23 This sounds suspiciously like an advocacy of Soviet or Cuban style collectivized farming, systems that have never been accused of being based upon "private appropriation." The Council proceeds to note five market distortions. ${ }^{24}$ Before examining these in detail, it is necessary to set into context the bishops' charges. Clearly located in the socialist camp, they are stating that markets, capitalism, free enterprise, etc., are to blame for the plight of the poor, and that government action, such as taking land from the rich and giving it to the poor, is the solution.

The first market distortion is the government's forcing of indigenous populations into artificial groups and locating them on reservations. The reservations are often located in "infertile areas, far

\footnotetext{
${ }^{22} I d$. para. 2.

${ }^{23}$ Id. para. 4.

${ }^{24}$ See id., para. 4 , n.5.
} 
from [economic] markets or poor in infrastructures." ${ }^{25}$ The problem is that the government, and only the government, has the legal power to force the geographic relocation of the populace. Additional examples of forced relocation include the creation and maintenance of a German ghetto for the Jews during World War II, zoning laws in general, and the "Jim Crow" legislation in the American South following the Civil War. The common denominator is that it is the state which imposes such mandates. How, then, can the blame rest with the market? Imprisoning specific portions of the population in infertile or otherwise inhospitable areas represents a- "government failure," not a "market failure."

The second market distortion is "the imposition of discriminatory taxes on the produce of small indigenous farmers." ${ }^{26}$ It can hardly be denied that this too is due to government action, not to market action. Ironically, this charge is most often raised by clergymen. The Church itself advocates discriminatory taxes in the form of land redistribution. Although the Church's redistribution plans generally favor the poor rather than the rich, who are traditionally the government's beneficiaries, both practices are discriminatory.

The third market distortion occurs when a pricing system is adopted that works in favor of large producers and to the disadvantage of small farmers. ${ }^{27}$ Price controls create this distortion and are clearly created by the government, not private citizens. Only the government has the legal power to impose price controls. A fourth distortion can be found in "the imposition of import barriers in order to protect the produce of large landowners from international competition." ${ }^{28}$ Again, only the state has the capacity to set up barriers to international trade. Such barriers are indeed serious impediments to economic growth and are in need of control or elimination.

The final market distortion involves "the provision of public services and subsidies from which only large landholdings could, in

\footnotetext{
${ }^{25} I d$. at $5($ a.).

${ }^{26} \mathrm{ld}$. at n.5(b).

${ }^{27}$ Id.at n.5(e).

${ }^{28}$ Id. at n.5(d).
} 
actual practice, benefit."29 At first glance, this seems consistent with laissez faire capitalism. However, it is the government and not the market that is providing the services and subsidies. Taken on its face, it seems the argument should be to end business subsidies because they represent a market distortion. Then, the so-called "public services" would be provided privately. This comports with the libertarian philosophy. ${ }^{30}$ However, the present authors believe that the Pontifical Council's document reflects the likelihood that the clergy may agree with this result more in principle than in practice.

\section{Industrialization at the Expense of Agriculture}

The Council's document is, for the most part, a socialist creed written in opposition to private property rights. Nevertheless, there are portions which support market theory and criticize government regulations. For example, the document attacks protectionism, exchange rate manipulation and price controls. ${ }^{31}$ Again, this comports with the classic liberal perspective. However, it is worth noting that the document appears to represent the product of a diverse committee composed of theologians with both pro- and anti-government sentiments. ${ }^{32}$ It is apparent that there was little communication between the divergent groups. ${ }^{33}$

\footnotetext{
${ }^{29}$ Id. at $\mathrm{n} .5(\mathrm{e})$.

${ }^{30}$ See Rothbard, supra note 12, at 194-241.

${ }^{31}$ See Presentation, supra note 14, para. 6.

${ }^{32}$ This has given rise to what can only be called the "Daddy likes me best" school
} of commentary. Since the PC has both pro and anti market elements, commentators from both sides have each stressed the parts of the document which favors their own position, and then claimed that the Church, or the Cardinal in this case, or the Pope in the case of several of the Papal Encyclicals, is "really on their own side." In sharp contrast, the present commentary has no ax to grind in this regard. If we say so ourselves, it is a straightforward political economic analysis of "Toward a Better Distribution of Land" which notes that it contains both support for, and criticism of, capitalism.

${ }^{33}$ Sometimes libertarians are accused of a similar sort of inconsistency, for we favor both economic (laissez faire capitalism) and political liberty (civil liberties, free speech). In contrast, the overwhelming majority of commentators favor either economic but not civil liberty (conservatives) or civil, but not economic liberty (socialists). To champion both is thus to be held internally self-contradictory. However, in the libertarian philosophy, freedom is a 
The Pontifical Council concludes that unwise government interventions in free enterprise have led to a "fall in farm income [which] has affected small producers so badly that many have been forced to give up farming." ${ }^{34}$ The Council assumes that there are negative consequences when people are "forced to give up farming." However, this is not necessarily so. In the United States, the market has similarly "forced" people out of farming. The result has been an increase in productivity within both the agricultural sector and the industrial sector. This has led to enhanced income and wealth.

Strictly speaking, of course, the market can never "force" anyone to do anything. The market simply consists of no more and no less than the concentration of all voluntary economic interactions. ${ }^{35}$ Perhaps a more accurate way of describing the process is that people are led by Adam Smith's "invisible hand" ${ }^{36}$ to do that which is in the best interests of the economy. It is a result of the market that people have moved from the farm to the city where productivity is higher. The market may exert economic pressure on farmers to move to the city, but any given farmer in the United States is free to remain where he is. The result has been simply that the farmer has had to accept a lower income because consumers place a higher value on goods made in the cities.

The Council, on the other hand, views the move toward industrialization as problematic per se. The Church clearly favors reduced poverty. However, at the same time, the Church seems to favor the maintenance of a farm-based economy. There appears to be a logical inconsistency here. The Church wants to improve the conditions of the poor but not at the expense of farming.

seamless web, which must be pursued in any and all directions. The contradiction, then, takes place on both of these other place on the political economic spectrum, not on our own patch of it.

${ }^{34}$ Presentation, supra note 14, para. 6.

${ }^{35} \mathrm{Cf}$. ROBERT NOZICK, ANARCHY, STATE, \& UTOPIA 163 (1974) (stating the market consists of "capitalist acts between consenting adults").

${ }^{36}$ See SMITH, supra note 19. 
D. Failure of Agrarian Reform

The Council discusses what it views as the reasons for the failure of past efforts in land reform. ${ }^{37}$ In addition to the concentration problem, there is a failure of "preventing the expulsion of large masses of peasant farmers from the land that is still free, but which may be marginal...." ${ }^{38}$ However, this argument can be shown to be incorrect. Given that free enterprise is the key to economic development of third world countries and that private property rights are integral to free enterprise, then anything which promotes private property rights should in turn reduce poverty. The right to expel farm workers, if they are no longer needed, is a component of private property. Therefore, be it ever so counterintuitive, the right of expulsion is actually a means of enhancing overall wealth.

Additionally, the Pontifical Council's opposition to "migration to urban centers" ${ }^{139}$ may be counterproductive. For example, the migration of black farm workers from rural states such as Mississippi and Alabama to urban areas such as Chicago, Detroit and Philadelphia during the 1940s and 1950s resulted in economic growth. Surely the Council can recognize that it would have been economically disadvantageous for people to have stayed on the farms.

Economists place great value on the phenomenon of "voting with the feet" as an indicator of economic well-being. If there is a migration lasting several years in duration then the newcomers can tell those still on the farm of the benefits of city life. If those who had remained subsequently migrate to an urban center, then that migration provides strong evidence that life is better in the new venue. Historically this pattern has occurred under various circumstances. For example, there was traffic by Jews out of Nazi Germany, not into it. Similarly, the Industrial Revolution was beneficial for poor peasants who migrated to cities in spite of the factory hardships portrayed by

\footnotetext{
${ }^{37}$ See Presentation, supra note 14 , para. 7.

${ }^{38} \mathrm{Id}$.

${ }^{39} \mathrm{Id}$.
} 
socialists such as Dickens. ${ }^{40}$ This pattern can also be found in preMandela Apartheid South Africa. It can be deduced that South Africa was better for blacks than the alternatives available elsewhere because migration was into South Africa. The migration patterns criticized in the Presentation demonstrate this pattern. When peasants continue to flock from farm to city, it is evidence that urbanization is an improvement in their lives. It is worth noting that churches are also clustered in cities and are less common in rural areas. The clergy too are "voting with their feet" by remaining largely urban.

\section{E. Contradictions}

The Pontifical Council seems to contradict itself when it calls for more government contributions to infrastructure as a necessary component of land reform and economic development. This is contrary to their notion that large landholders, not poor peasants, tend to benefit from these social services and subsidies. ${ }^{41}$ Infrastructure generally includes items such as roads, harbors, lighthouses, electricity, other power sources, libraries and public universities. Socialism is hardly the best way to provide such items. There is little doubt that private capital would be able and willing to invest in the infrastructure. However, the Council does not explain why it believes socialism will succeed and the market will fail in this regard.

The Pontifical Council also calls for "fixing prices" in order to enhance economic development. ${ }^{42}$ This is in direct contradiction to its opposition to "control of food prices." ${ }^{.43}$ It is clear that both cannot be correct. Either price controls are a force for economic development or they are not. Clearly, only the latter is correct. Prices have a role to play in economic growth. Prices coordinate the decentralized behavior of millions of consumers, sellers, entrepreneurs, workers, resource 1966) (1842).

${ }^{40}$ See Charles Dickens, Oliver Twist (Kathleen Tillotson ed., Oxford Press

${ }^{4}$ See Presentation, supra note 14, para. 7.

${ }^{42}$ ld. para. 8.

${ }^{43}$ Id. para. 6. 
owners and middlemen. ${ }^{44}$ In this manner, uncontrolled prices based on private property coordinate the market. The only other alternative is central planning, which has always proven unsuccessful. The economic collapse of the Soviet Union is evidence of the negative effects of cental planning.

The Council intends that "land reform" extend beyond taking the property of some and giving it to others. In addition to land redistribution, the Council calls for subsidies, subsidized credit, grants, government funded improvements in infrastructure, "social services," and price fixing or price controls. ${ }^{45}$ Clearly such programs require a great deal of money. The burden is likely to be borne by the taxpayers. Not only have taxpayers not been at all implicated in the (possible) Latifundista land theft that contributed to land inequality, they are also less likely to benefit from the proposed improvements. Furthermore, the programs proposed are incompatible with free enterprise. Finally, the Council recognizes that past attempts at land reform have been accompanied by massive corruption; yet, the Council favors this course of action without providing any means to prevent corruption from again occurring.

F. The Management of Agricultural Exports

\section{Debt Repudiation}

As in the case of land reform, the libertarian can agree with the socialist as to the propriety of debt repudiation, at least in principle, while disagreeing as to the specific justification. In contrast, the conservative, with an imprecise understanding of private property, rejects this course of action outright. The left wing individual defends both land reform and debt repudiation on egalitarian grounds believing that as long as the poor gain, the case is made.

\footnotetext{
${ }^{44}$ See MiSES, supra note 1 , at 53; see also F.A. HAYEK, THE CONSTITUTION OF LIBERTY 112 (1960).

${ }^{45}$ See Presentation, supra note 14, para. 8.
} 
Consider for example an illegitimate government, such as in Cuba. Suppose that a new libertarian regime somehow takes over this troubled island nation. Does this new government have the responsibility to pay off the creditors of Fidel Castro and his fellow criminals? People who have purchased Cuban bonds fall into two classes: those who did so under duress, and those who made willing contributions, either out of ideological support for Cuban style communism, and/or because the interest rates were attractive to them. The determination of whether to pay the latter is quite simple. Those willing lenders were cooperators, or perhaps even conspirators, with a government that is composed of criminals. Therefore, no repayment is necessary; indeed, it would be highly improper. The payment obligation is not as easy to determine in the situation where innocent people were forced to buy Castro's bonds. Yes, they should be able to sue Fidel and his minions in order to collect their debt. Their lien against these people should be a high one. In that sense, there is no debt repudiation. On the other hand, it would be totally impermissible for the new regime to tax innocent Cubans to repay these debts. To do so creates a new set of innocent victims to compensate the first set of victims.

Of course, a practical question to consider along with repudiation is the future impact on borrowing. Repudiation makes it is less likely that new borrowing will occur. Further, a substantial difference exists between socialists repudiating debt because the lenders are rich and the borrowers poor, and the libertarians doing so because the lenders have cooperated with thieves. In the former case, the bond market may close off entirely or charge such high rates of interest as to impede future borrowing. With the latter case there is not enough historical evidence to render an opinion about this essentially empirical issue.

\section{Agrarian Dualism}

It is almost an article of faith amongst clerical commentators on business subjects that selling goods for the export market is uneconomic. According to the Council, "[i]f the market prompts small 
farmers to grow export crops, this often takes place at the expense of production intended mainly for their own consumption, thus putting farming families at considerable risk." ${ }^{46}$ This view amounts to economic illiteracy. The only way the market can "prompt" anyone to do anything, farmers or industrialists, large or small, is by holding out the prospect of greater profits. Should American wheat farmers stop their production for export, and instead produce something consumed in the U.S., such as apple pie? Should German exporters of Volkswagens cease and desist, and instead manufacture wienerschnitzel, something beloved of local consumers? Should a small family firm in the tulip bulb industry of Holland cancel production for the world market because "unfavorable climatic or market conditions can lead to a vicious circle of hunger, so that such families contract debts that then force them to give up ownership of their land" ${ }^{47}$ To ask these questions is to answer them.

The business world is unpredictable. Indeed, it is the essence of the entrepreneurial function to bear risk. There are no guaranteed safe havens - any businessman, no matter how powerful, must risk financial loss. This applies to exporters and importers, as well as those who produce for the local market. Self-sufficient family farms, beloved of the clergy, like small family groceries, can also prove to be uneconomic.

It is one thing to use the cloak of theology to give good business consulting advice; even this is problematic, as it exceeds the competence of the authors. It is quite another to give erroneous opinions, cloaked under the authority of the Church, which might well be believed by unsophisticated people in the third world. This is no way to promote the "preferential option for the poor." 48

${ }^{46} I d$. para. 10.
${ }^{47} I d$.
${ }^{48} I d$. para 2. 
G. Expropriation of the Land of Indigenous Populations

According to the Council, "the rights of the indigenous inhabitants have been ignored when the expansion of large scale agricultural concerns ... (and industry) ... have been decided . . . "149 The clergy are absolutely correct in claiming that Indian lands have been stolen throughout history. They are on morally firm ground in implying that these wrongs should be righted, despite claims to the contrary from conservatives who favor the status quo in terms of land ownership, believing that any forced changes would be a violation of private property rights.

However, the clergy here tread on thin ice in several regards. First of all, "large scale" agriculture, hydroelectric, mineral, oil and timber interests are not the only ones to have ridden rough shod over native property rights. Small concerns have also done so. Second, these thefts, or takings, are by no means as extensive as thought of in some quarters, at least on Lockean grounds. The fact of the matter is that we are talking about people with essentially stone-age technology who were for the most part incapable of homesteading property. Much, but not all, tribal behavior consisted of hunting and gathering, not in mixing their labor with the land as in farming. To be sure, then, such people would be the legitimate owners of all the berries they had gathered and animals they had killed, etc., as well as of their northern and southern camping grounds, and the right of access from one to the other. But a mere handful of natives could not have homesteaded anything approaching the entire territory of the continental United States before the arrival of the Europeans. The point is, LockeanLibertarian homesteading theory requires that the Indians mix their labor with the land; that they transform it in some way. This, for the most part, they failed to do, and therefore cannot be considered its legitimate owners. While they would be considered proper owners of the relatively small areas where they pitched their tents and farmed, they would not be the owners of the vast areas in which they traveled and hunted.

\footnotetext{
${ }^{49}$ Id. para. 11.
} 
Finally, "the burden of proof" rests with those who wish to alter property titles. Otherwise, we are reduced to claim theory for all property. An individual can claim he is the rightful owner of another's land or wristwatch, but unless he can offer proof of his contention there is no warrant for transferring these items from the one to the other. Yet, the Council goes so far as to admit that "the origins of" Indian ownership claims to land "are lost in memory." 50 If so, how can any rational court grant these claims? They state, further that "[i]ndigenous populations can also run the absurd but very real risk of being seen as 'invaders' of their own land." ${ }^{51}$ But where is it engraved in stone that this is "their own land"? If they never in justice owned the land in the first place, and then others arrived who did homestead it, then it is not at all incorrect to characterize the natives as "invaders," not of their own land, but of the land of these later arrivals.

The libertarian theory is not merely an excuse for the status quo, as is that of the right wing. It is not merely the dressing up in more sophisticated clothing of the conservative head in the sand attitude toward land reform. Yet it may well appear this way when we consider very ancient wrongs, or those done to people with stone-age technology who thus have no written records to support their claims. However, with regard to more recent events where there is physical evidence of robbery (e.g., the Nazis and the Jews, the Americans and the Japanese in the early 1940s, and even black pre-civil war slavery in the United States) the libertarian and conservative conclusions as well as underlying analyses are very different.

\section{H. Violence and Complicity}

The clerics quite properly oppose "terror." But one man's terror may be another man's self defense. Property rights are the only way to tell if A's fist is imposing on B's face, or if B's face is attacking A's fist. Consider again Professor Rothbard's analysis of "A, seizing B by the

${ }^{50} I d$. 
wrist and grabbing B's wristwatch." 52 Who is aggressing against whom in this action? It all depends upon who is the rightful owner of the timepiece. If the property belongs to $B$, then $A$ is indeed the terrorist.

The same thing appears to have occurred between the latifundistas and the landless peasants. The clergy see the former as using violence on the latter, and too quickly assume they are guilty of terror. But if the land properly belongs to the large latifundistas, then all those who squat on their property, or trespass upon it, or attempt to take it over, are the real criminals. Property rights determine terror; without this understanding, we cannot possibly distinguish an invasion from self defense.

Suppose that landless peasants "sat in" on church property, attempting to turn these edifices devoted to worship to housing for themselves. Would not the reaction of the priest be to call in the police for eviction, thus resorting to what these trespassers would see as "terror"? And what of the defense of "protests of workers who are forced to work at an inhuman pace for wages that often do not cover their travel and living expenses." ${ }^{53}$ This Council charge is economically incomprehensible. The wage depicted by the clergy would have to be below that of subsistence level. Even slaves were paid a wage greater than "living expenses" in terms of food and shelter; otherwise they would have perished. Wages are determined in markets based on productivity. This must of necessity be higher for free men than slaves, if only because there are no costs of guarding the former from escape which must be deducted from the former's productivity. Thus, ceterus paribus, free labor must always be paid more than slaves. And if slaves are paid enough to keep them alive, free persons must be paid even more. Thus, this charge is an untenable one.

\section{Legal Recognition of Ownership Rights}

The Council complains of the fact that it is difficult "for small farmers to obtain legal recognition of ownership rights over land that

${ }^{52}$ See supra text pp. $3-8$.

${ }^{53}$ Presentation, supra note 14, para.12. 
they have been farming for a long time and of which they are the de facto owners." The problem with this is that there can be no such thing as de facto ownership, where a different person has actual title to the land, and is thus the de jure owner.

How could such a situation arise? One possibility would be for a tenant to farm land for many years for an absentee owner, and then, suddenly, to declare that he, the farmer, was the real owner, and that the landlord to whom he had been paying rent for decades was not. Another would be the case of an owner of land who allowed a passerby to take a shortcut through his property, so much so that over the years a path was worn by his footsteps; whereupon the traveler, instead of being grateful to the owner, asserts his access rights.

Were this sort of thing countenanced by the courts, it would place into disrepute private property, and with it, capitalism, the system which has brought about modern civilized standards of living. Alternatively, no one would ever allow passerby access to one's land; and tenancy would become a thing of the past. This would run counter to the preferential option for the poor, as they are people of limited means, who cannot afford to buy homes, cars, farms, etc., and are thus the main beneficiaries of tenancy.

\section{J. Environmental Concerns}

The authors of this report worry that without seizing the land of the latifundistas, there will be an "over-exploitation of natural resources without concern for environmental sustainability or without considering the intergenerational continuity of family property." ${ }^{54}$ Environmental degradation, running out of resources, extinction of species, and other legitimate environmental concerns simply have nothing to do with who owns the land, provided only that it is held in private, not public, hands. The reason for this is rather straight forward.

${ }^{54} I d$. para. 14. In another section, the clerics express the view that "inequalities in the distribution of land ownership set in motion a process of environmental degradation that is hard to reverse." Id. para. 21. For a critique of this sentiment, see Pollution Trading Permits as a Form of Market Socialism, and the Search for a Real Market Solution to Environmental Pollution, 1 FordHAM ENVTL. L.J. 46, 51-57(1994). 
When an individual or family farmer or large firm in the agriculture business industry owns land, or a cow, or a tractor, they tend to take care of them. They do not overuse these resources, or dissipate them. If they fail to act in this manner, they suffer the full attendant losses.

In very sharp contrast, when items such as these are owned in common through coercion, when no one really owns them but all may partake in their use, they are in great danger. Under such circumstances, the user is not confronted with the full costs of his actions. For example, a farmer would be foolish to allow his sheep to graze too long on his own land, since if he does, the grass will be eaten down to its roots, and will not regrow easily. He has every incentive to preserve this land for another day, for if he does, he is assured that his sheep will be the ones who benefit. On the other hand, if the pasture is compulsorily held in common by all shepherds, then none of them has an economic incentive to act in this environmentally and economically sound way. Here, if he moves his sheep up the mountain to another less accessible pasture, he has no guarantee at all that when he returns to the more convenient one, the grass will be held for his animals. On the contrary, it is almost certain that someone else will come along and allow their sheep to overgraze.

\section{K. The Credit Market}

The Council takes the position that "[i]n rural areas, there is often no legal credit market, so that small farmers have to turn to money lenders if they need loans, thus exposing themselves to risks that can lead to the partial or even total loss of their land -- for property speculation is usually the real focus of such moneylenders' operations." ${ }^{55}$ There are numerous economic fallacies espoused here. First, a confusion exists in the passage between the geographical and the legal spheres. Lack of a legal credit market results from jurisprudence and not location. When an enactment forbids credit, or sets interest rate maximums, it can apply to either rural or urban areas.

${ }^{55}$ Presentation, supra note 14, para. 15. 
No presumption exists, as the clergymen contend, that this law applies with greater feverishness to the rural milieu rather then the urban.

Secondly, money lenders are part of the credit market. While the clergy thinks all money lenders loan at very high rates, this is not always the case. Basically, what determines the rate of interest in a given society is time preference: the impatience of the populace to consume now, as opposed to deferring gratification for the future. If the former, then a high interest rate ensues; if the latter, a low one. Imagine a society composed primarily of seven year old school children, each of whom would gladly give up five candy bars tomorrow to have one today. Very few of them would be willing to lend at almost any interest rate, and most would be willing to borrow at virtually any cost. Interest rates will thus be very high, regardless of other occurrences. At the opposite end of the spectrum are people who "save for a rainy day." They are willing to lend money even at low rates of interest, and rarely borrow, even when it is cheap to do so. A low interest rate will prevail in such a society. In other words money lenders, and the interest rates they charge, are merely the messengers for the underlying economic realities. ${ }^{56}$

Finally, the real cause of artificially high interest rates stems from laws prohibiting usury. Imposing ceilings upon interest payments creates a situation where only individuals with good collateral obtain loans, which tend to be large enterprises. Small businesses and other risky borrowers with little collateral and poor repayment records have to deal in the black market, at much higher interest rates because of the laws against usury; the lender, as a law breaker, cannot rely upon the courts to help collect bad debts. Only exorbitant interest rates compensate a lender enough to risk loans to such enterprises. This means that the "risks" are borne not by the small borrowers whose interests the Counsel think they are defending, but by the usurious money lenders. The small and/or risky borrower does not face risk, but

${ }^{56}$ For more on this subject, see MURRAY ROTHBARD, MAN, ECONOMY AND STATE 74-120 (1993); EUGEN BOHM-BAWERK, CAPITAL AND INTEREST 35 (George Hunke \& Hans Sennholz trans., Libertarian Press 1959) (1884); Walter Block, The Negative Rate of Interest: Toward a Taxonomic Critique, 2 J. LIBERTARIAN STUD. 121, 124 (1978). 
rather faces either astronomical interest to attract the loan or the inability to obtain financing at all.

Property speculation, or any other kind, does not represent the evil that the Council believes. Instead, the market process of speculation places goods and services into the hands of those who value them greatest, as demonstrated by willingness to pay. The speculator helps stabilize price differentials so that the same price for the same commodity, apart from transportation and other such costs, prevails everywhere. For example, if oranges are selling for one dollar in Miami and two dollars in Boston, the speculator will take advantage of this difference by purchasing cheap southern oranges and transporting them north. The first part of this operation raises the prices of oranges in Miami, and the second part lowers them in Boston.

While money lenders may sometimes speculate in land, and land speculators may sometimes lend money, the two professions are not at all economically connected, as the clergymen espouse. The only common bond between lenders and speculators mirrors the bond between middlemen and landlords: All four are cordially hated by socialists as emblematic of capitalism.

\section{Idle Land}

The Counsel states, with regard to the case for breaking up the Latifundias, and redistributing them to the landless poor, that "[s]uch large landholdings are often poorly cultivated, or simply left uncultivated for speculation .... "57 If these holdings represent stolen property then a strong moral case exists for redistributing them not to the poor, but to the children of the victims. However, to offer "poor cultivation" as a reason for land reform implicitly acknowledges the legitimacy of these property titles; in effect, the clergy argue that, even if the latifundistas had clear and legitimate title to their lands, they should still lose their land on grounds of poor cultivation.

If true, more land would exist to redistribute than to merely the latifundias in the third world. Anything left idle would be fair game.

${ }^{57}$ Presentation, supra note 14 , para. 32. 
For example, Mr. A goes on a year long holiday for a trip around the world. He leaves his home vacant and loses ownership in it. Mr. B doesn't use his fifteen speed bicycle, tennis racket or fishing rod for five years; long before that time, his property rights in these items lapse. Miss C doesn't wear her blue dress for a few years, with the same result. Farmer $D$ utilizes his land only eight months of the year, allowing it to lie fallow for the remaining four months. A teenager leaves his childish toys in the attic; when he tries to recover them, he is told he no longer owns them. An old man sticks his money in his mattress for years, "for a rainy day," and thereby loses it.

The problem of this philosophy, apart from the blatant unfaimess of seizing idle property, is that it disregards Keynes' "precautionary motive." 58 People value their possessions whether they "use" them or not. Alternatively, and perhaps preferably, people do not always use them in normally accepted standards. The point is, Mr. A's home, Mr. B's sports equipment, Miss C's dress, Farmer D's land, the teenager's toys and the old man's money are not really "idle." They only appear so to outsiders. One man's lack of cultivation or idleness is another man's valuable contemplation or financial support against the unknown future. If the goods did not provide services, if they were truly idle, they would be sold. Thus, people occasionally sell their homes, dresses, toys, etc. Are there no Church owned bibles, organs, churches, surplices, wine, automobiles, or wafers that go unused for any appreciable amount of time? If so, these would be forfeited under the philosophy adumbrated by the Council.

\section{The Lack of Infrastructures and Social Services}

In the view of the Pontifical Council, "small farmers are forced to depend on local markets to sell their produce... They are also dominated by traders whose monopolistic position means that farmers are forced to accept the price offered if they want to sell their

\footnotetext{
${ }^{58}$ JOHN MAYNARD KEYNES, GENERAL THEORY OF MONEY, INTEREST AND MONEY 215-225 (1936).
} 
produce. ${ }^{159}$ The clergymen illuminate an important issue, but their lack of economic sophistication distorts its perception. The clergy raise the issue of marketing boards, which are government entities that prohibit farmers from selling to anyone but themselves. Also, the boards typically purchase at prices far below levels farmers could otherwise attain, whether on local or world markets. ${ }^{60}$ These monopsonists ${ }^{61}$ exploit farmers, particularly small ones who cannot bribe their way out of these regulations or otherwise avoid them.

The flaw with the cardinal's analysis is that the boards are government entities, not a part of the market. To label them "traders" confuses markets with central planning and economic freedom with economic coercion. Nor could it be otherwise. If these underdeveloped countries were dedicated to capitalism, then any local private person would be a monopsonist who served as the sole purchasing agent for small farmers and bought at below world market prices, would earn vast profits. However, this would attract other competitors into the industry, both local and multinational, which would compete with the original monopsonistic one to buy farm produce. With greater demand, prices paid to farmers, even small ones, would increase until the profits earned in the industry reached market standards, abstracting from risk.

Why, then, do the clergy, being aware of monopsonistic exploitation of small farmers, not call for an end to governmental marketing boards? Presumably, the answer is that they have cast their lot, and their moral authority, with socialist central planners, not free enterprise, and marketing boards play an integral role in this philosophy. To frontally attack statist marketing boards would undermine their moral and intellectual underpinnings.

\footnotetext{
${ }^{59}$ See Presentation, supra note 14 , para. 17.

${ }^{60}$ See generally supra note 19 and accompanying text.

${ }^{61} \mathrm{~A}$ monopsonist is the opposite of a monopolist. The monopolist is the only legal
} seller (e.g., the post office, a medallioned taxi cab) in a given market, while a monopsonist is the only legal buyer ( a marketing board to which all farmers are forced to sell). Under this system, it is illegal to sell agricultural products to anyone else other than the official marketing board. 


\section{N. Economic Consequences}

The Council complains of "the pegging of farm wages at low levels". $^{62}$ "Pegging" refers to governmental setting of wage rates. Pegging at levels below equilibrium would be equivalent to setting wage maximums. This can cause labor shortages. The clergy, perhaps unfamiliar with technical economic usage, do not refer to this situation. Instead, somewhat confusingly, they mention ordinary functioning of the labor markets and not governmental interference. To wit "this pegging is a result of the simultaneous rise in supply and fall in demand for farm labour." 63

If true, it causes both happiness and regret. Farm workers will receive less compensation, which means they are not needed in agriculture, but, rather, they are in relatively greater demand elsewhere, presumably in industry. If so, this would roughly follow the United States pattern, where virtually the entire populace engaged in farm labor in the 18th century and virtually no one farms at the close of the 20 th century ${ }^{64}$

\section{CONCLUSION}

There is massive suffering on the part of the poor in the underdeveloped countries of the world. However, this is due to central planning, socialism, and a public ethic which views with great suspicion profits, free markets, individual initiative, and entrepreneurship -- it is not at all the fault of free enterprise and private property rights.

This story exists the world over. Well meaning critics, ignorant of the niceties of economic science, see abject poverty and misinterpret its causes. They have still to learn Adam Smith's lesson that the wealth of nations stems from economic freedom, not its absence. The theological critics fail to see the deleterious effects of government

\footnotetext{
${ }^{62}$ Presentation, supra note 14, para. 18.

${ }^{63}$ Id.

${ }^{64}$ See The Statistical AbSTRACt OF the Untred States (1998).
} 
theological critics fail to see the deleterious effects of government control and, instead, espouse the same policies that created the plight of the poor in the first place.

It cannot be denied that there has been land theft, occurring in both the economically underdeveloped part of the globe and the developed nations. Land reform, based on returning stolen property from the children of the thieves to the children of the victims, is justified. But the burden of proof must reside on those who would overturn extant property titles. This requirement vitiates against the undoing of robbery buried in the sands of time, against the very poor who do not have access to records which can prove their claims, and against native peoples lacking written records. Thus, while the libertarian message on land reform is a very radical one in theory, it is rather conservative in application. It is radical in theory because it is open to the possibility, which is rather unexpected given its almost total unanimous rejection on the part of those who ostensibly favor private property rights. ${ }^{65}$ On the other hand, as a practical matter, the libertarian perspective on land reform cannot be expected to support changes in extant land titles between Jews, Arabs, Palestinians, etc., since their disputes go back for thousands of years; nor for Indians vis-a-vis white settlers in the United States for lack of written records. This view may, however, buttress claims from Japanese Americans stemming from World War II expropriation.

If the church wishes to promote the interests of the poor, if it desires to take to heart "the preferential option for the poor," instead of continually urging socialistic welfare schemes that only impoverish them, it must make itself more knowledgeable about economics. Then, as easy as falling off a log, the clergy will realize that the last best hope for the poor are the institutions of free enterprise, precisely the ones responsible for the relatively vast wealth enjoyed in the western industrialized nations.

\footnotetext{
${ }^{65}$ See Tom Bethell, The Noblest Triumph: Property and Prosperity Through THE AGES 35 (1998). For a response, see Walter Block, Review Essay of Tom Bethell, 3 Q. J. AUSTRIAN ECON. 65 (1999).
} 
